\title{
Chest X-ray: an examination that has been in use for centuries but is still essential, especially in the clinical management of newborns in the neonatal intensive care unit
}

\author{
Radiografia de tórax em unidade de terapia intensiva neonatal: um exame transecular, mas ainda essencial
} no manejo clínico dos recém-nascidos

\section{$\overline{\text { Sara Reis Teixeira }{ }^{1}, \text { Aline }^{\text {Naves }}{ }^{2}}$}

The most common causes of admission to a neonatal intensive care unit (NICU) are prematurity and low birth weight, which collectively account for up to $69 \%$ of hospitalizations in referral NICUs, including those in Brazil ${ }^{(\mathbf{1 - 4})}$. Respiratory complications, notably respiratory distress syndrome of prematurity, are major causes of mortality in the $\mathrm{NICU}^{(3,4)}$.

In the management of neonatal lung diseases that require NICU admission, chest radiography plays a fundamental role in the initial diagnosis of major clinical alterations of the respiratory profile and is the standard procedure to determine the positioning of probes, tubes, and catheters ${ }^{(5)}$. Despite the technological advances in diagnostic imaging, with the addition of various new modalities in recent decades, chest radiography continues to be the most widely used radiological modality in $\mathrm{NICUs}^{(6)}$.

Atelectasis is a common pulmonary alteration that can cause a sudden worsening of the clinical condition of a neonate, predisposing to infectious complications and increasing the need for ventilatory support ${ }^{(7)}$. Atelectasis is a sign of disease and, in isolation, is not suggestive of a specific diagnosis; hence, the need for clinical correlation. The treatment of atelectasis varies depending on its cause, duration, and severity $^{(\mathbf{8 , 9})}$. The main mechanisms for the formation of atelectasis are airway obstruction, extrinsic compression, and increased surface tension between alveoli and bronchioles due to surfactant deficiency ${ }^{(9)}$. The main diseases that affect newborns with atelectasis include respiratory distress syndrome, meconium aspiration syndrome, pneumonia, pleural effusion, and pneumothorax ${ }^{\mathbf{8})}$. Atelectasis can also be a consequence of inappropriate positioning of the endotracheal tube, which

1. MD, PhD, Attending Physician at the Centro de Ciências das Imagens e Física Médica (CCIFM) of the Hospital das Clínicas da Faculdade de Medicina de Ribeirão Preto da Universidade de São Paulo (HCFMRP-USP), Ribeirão Preto, SP, Brazil. E-mail: steixeira@hcrp.usp.br.

2. MD, Physician at the Centro de Ciências das Imagens e Física Médica (CCIFM) of the Hospital das Clínicas da Faculdade de Medicina de Ribeirão Preto da Universidade de São Paulo (HCFMRP-USP), Ribeirão Preto, SP, Brazil. prevents adequate ventilation of the newborn ${ }^{(\mathbf{1 0})}$. Therefore, the detection of a malpositioned endotracheal tube should prompt its immediate correction ${ }^{(\mathbf{1 1})}$.

In this issue of Radiologia Brasileira, Alvares et al. ${ }^{(12)}$ discuss the role of chest X-ray in the evaluation of atelectasis in newborns with clinically treatable lung diseases, as well as its main forms of presentation, causal factors, and associated conditions, such as malposition of endotracheal tubes. The authors found that the endotracheal tube was positioned incorrectly in $87 \%$ of the patients and that malpositioning of the endotracheal tube was associated with prematurity and with a birth weight below $1000 \mathrm{~g}^{(\mathbf{1 2})}$. They also identified a trend towards an association between atelectasis in the upper lobe and malpositioning of the head. Their results corroborate those of other studies reporting that extremely-lowbirth-weight infants are more vulnerable to incorrectly placed tubes $^{(\mathbf{1 1})}$. In addition, the malpositioning of the head of the neonate during conventional radiography is also a predisposing factor for inappropriate tracheal intubation, which can lead to atelectasis and adverse respiratory outcomes ${ }^{(\mathbf{1 1}, \mathbf{1 3})}$. A distal positioning of the endotracheal tube occurs when the head is flexed, whereas proximal positioning occurs when the head is extended ${ }^{(\mathbf{1 3})}$.

Radiographs performed in the NICU result in increased exposure to ionizing radiation, not only for newborns, who are more sensitive to radiation than adults, but also for the NICU staff. Such radiographs also increase the risk of accidental removal of catheters or tubes and, consequently, intubation failure $^{(\mathbf{1 4})}$. It is necessary to be aware of ionizing radiation dose reduction techniques and even to consider the use of other imaging modalities, such as ultrasonography ${ }^{\mathbf{( 1 5 )}}$. To guarantee the quality of the examination and avoid additional exposure to ionizing radiation, with adequate attention paid to penetration, lung expansion, positioning of the neonate, and, especially, collimation is of great importance ${ }^{(16)}$. Although ultrasonography has been shown to be an alternative to conventional 
radiography for determining the position of the endotracheal tube, chest X-ray continues to be the gold-standard modality for this purpose ${ }^{(\mathbf{1 4 , 1 7 )}}$. Incorrect positioning of the newborn and malpositioning of the endotracheal tube can cause atelectasis. However, they are modifiable factors and can be directly controlled by the radiologist. With cautious, radiologists can contribute to improve outcomes in neonates.

\section{REFERENCES}

1. Damian A, Waterkemper R, Paludo CA. Perfil de neonatos internados em unidade de tratamento intensivo neonatal: estudo transversal. Arq Ciênc Saúde. 2016;23:100-5.

2. Granzotto JA, Mota DM, Real RF, et al. Análise do perfil epidemiológico das internações em uma unidade de terapia intensiva neonatal. Rev AMRIGS, Porto Alegre. 2012;56:304-7.

3. Jacob J, Kamitsuka M, Clark RH, et al. Etiologies of NICU deaths. Pediatrics. 2015; 135:e59-65.

4. Feria-Kaiser $\mathrm{C}$, Furuya ME, Vargas $\mathrm{MH}$, et al. Main diagnosis and cause of death in a neonatal intensive care unit: do clinicians and pathologists agree? Acta Paediatr. 2002;91:453-8.

5. American College of Radiology. ACR Appropriateness Criteria - Intensive Care Unit Patients. [cited 2018 Jan 2]. Available from: https://acsearch.acr.org/docs/ 69452 /Narrative/.
6. Wilson-Costello D, Rao PS, Morrison S, et al. Radiation exposure from diagnostic radiographs in extremely low birth weight infants. Pediatrics. 1996;97:369-74.

7. Thomas K, Habibi P, Britto J, et al. Distribution and pathophysiology of acute lobar collapse in the pediatric intensive care unit. Crit Care Med. 1999;27:1594-7.

8. Alvares BR, Pereira IMR, Mezzacappa MA, et al. Atelectasia pulmonar em recémnascidos: etiologia e aspectos radiológicos. Sci Med. 2012;22:43-52.

9. Peroni DG, Boner AL. Atelectasis: mechanisms, diagnosis and management. Paediatr Respir Rev. 2000;1:274-8.

10. Kuhns LR, Poznanski AK. Endotracheal tube position in the infant. J Pediatr. 1971;78:991-6.

11. Thayyil S, Nagakumar P, Gowers $\mathrm{H}$, et al. Optimal endotracheal tube tip position in extremely premature infants. Am J Perinatol. 2008;25:13-6.

12. Alvares BR, Dominguez MC. Atelectasia pulmonar em recém-nascidos com doenças clinicamente tratáveis submetidos a ventilação mecânica: aspectos clínicos e radiológicos. Radiol Bras. 2018;51:20-5.

13. Rost JR, Frush DP, Auten RL. Effect of neck position on endotracheal tube location in low birth weight infants. Pediatr Pulmonol. 1999;27:199-202.

14. Ioos V, Galbois A, Chalumeau-Lemoine L, et al. An integrated approach for prescribing fewer chest x-rays in the ICU. Ann Intensive Care. 2011;1:4.

15. Dalmazo J, Elias Jr J, Brocchi MAC, et al. Radiation dose optimization in routine computed tomography: a study of feasibility in a University Hospital. Radiol Bras. 2010;43:241-8.

16. Souza RM, Baldisserotto M, Piva JP, et al. Uso da radiografia de tórax na unidade de tratamento intensivo pediátrico. Sci Med. 2013;23:191-8.

17. Hiles M, Culpan AM, Watts $C$, et al. Neonatal respiratory distress syndrome: chest X-ray or lung ultrasound? A systematic review. Ultrasound. 2017;25:80-91.

This is an open-access article distributed under the terms of the Creative Commons Attribution License. 